\title{
National Identity Formation under Statelessness: Experience of Ukraine in Soviet Times
}

\section{Формування національної ідентичності в умовах бездержавності: досвід України в радянський період}

Received: June 15, 2020

\begin{abstract}
The issue of national identity is multifaceted, disputable and extremely important in modern society, being one of the factors that determine its vitality. This paper presents the look at the problem from pedagogical perspective. The authors aim to explore the peculiarities of the formation of Ukrainian national identity in native intelligentsia under Ukrainian statelessness in Soviet times using the life and activity of Yurii Stupak as an example. Yurii Stupak is a notable representative of Ukrainian intelligentsia, an educator, scholar, literary studies expert, art critic, local history researcher, the author of numerous works in history of education and ethno-pedagogy. The study uses qualitative methodology and is founded on the laws and categories of scientific research. The researchers applied modern research approaches (personality oriented, cultural, personified, interdisciplinary) and methods (general scientific analysis, comparison, generalization, systematization; textual analysis, elaboration of the source base and historiographical work on the selected problem; the method of retrospective analysis). The authors have established that formation of the personality of Yurii Stupak as a teacher and scholar was influenced by numerous socio-political, socioeconomic, cultural-educational and personal factors. The authors prove the decisive impact of family education and learning from nationally conscious teachers at higher education institutions as well as self-education and will for constant personal and professional development on
\end{abstract}

Accepted: August 21, 2020

\author{
Written by: \\ Olena Pokhilko ${ }^{28}$ \\ https://orcid.org/0000-0003-1247-146X \\ Iryna Ivanova ${ }^{29}$ \\ https://orcid.org/0000-0001-9873-1677 \\ Daria Martynenko ${ }^{30}$ \\ https://orcid.org/0000-0002-5123-6473
}

\footnotetext{
${ }^{28} \mathrm{PhD}$ in Education, Sumy State University, Lecturer of the Chair of Language Training for Foreign Citizens, Ukraine.

${ }^{29} \mathrm{PhD}$ in Education, Associate Professor, Sumy State Pedagogical University named after A. S. Makarenko, Head of the Chair of Russian Language, Foreign Literature and Methods of their Teaching, Ukraine.

${ }^{30} \mathrm{PhD}$ in Education, Sumy State Pedagogical University named after A. S. Makarenko, Lecturer of Chair of Pedagogics, Ukraine.
} 


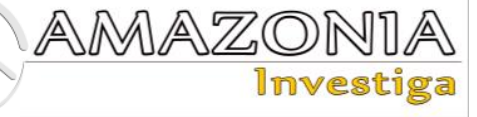

facilitating the continuity of the process of formation of Ukrainian national identity in the native intelligentsia during the investigated period. It is confirmed that national identity does not depend on the existence of sovereign statehood, but it stimulates its revival.

Key Words: national identity, Soviet time, statelessness, Ukrainian experience, Yu. Stupak. сознательных преподавателей высших учебных заведений, самовоспитания и стремления к постоянному личностному и профессиональному

самосовершенствованию на непрерывность процесса формирования украинской национальной идентичности в отечественной интеллигенции в течение исследуемого периода, чему не помешало даже отсутствие собственной государственности. Авторами доказано, что национальная идентичность не зависит от наличия суверенного государства, но она стимулирует его возрождение.

Ключевые слова: национальная идентичность, советские времена, бесгосударственность, украинский опыт, Ю. Ступак.

research papers on the history of pedagogy and ethno-pedagogy, one of the first educators of the Soviet era, who appealed to the folk-pedagogical sources of education of the younger generation. His conscientious and productive work in the educational field contributed to the formation of several generations of not only skilled but also nationally conscious teachers-practitioners.

\section{Theoretical framework}

The study of Ukrainian national identity formation in the native intelligentsia under the Ukrainian statelessness in Soviet Union times requires exploration of historiographic works of Ukrainian scholars, among which we distinguish the memoirs and other works of direct participants of the process, as well as archival sources.

The concept of identity attracts the attention of scholars from different regions of the world (I. Martínez, E. Rodríguez, T. Makarova, etc.) In Ukraine the problem of national, socio-cultural, regional identity is interdisciplinary, so scholars from both the social science and humanities (O. Mandebura, T. Potapchuk, T. Tatanenko, etc.) have addressed it in their works. The peculiarities of formation and transformation of this phenomenon have become the subject of attention of researchers when considering more general issues, such as the development of education, science and culture on the territory of Ukraine in the Soviet period (V. Artyukh, L. Berezivska, O. Homotiuk, G. Ivanushchenko, M. Kostytskyi, M. Pantiuk, V. Pitov, I. Prokop, V. Sadivnichy, O. Sukhomlisnka, O. Cheremska and others), their formation as separate 
institutions

(V. Bakirov,

L. Korzh, O. Riabchenko, M. Yarmachenko, etc.), the position of educators and pedagogical intelligentsia (M. Bystra, O. Bulgakova, O. Kashaba, V. Marochko, L. Misinkevych, G. Hillig, etc.). The memoirs and other works of the direct participants of this phenomenon make a significant part of the source base of the problem under study (O. Vertii, M. Danko, Y. Sambros, Yu. Stupak, O. Sukhomlynska, V. Sukhomlynsky, etc.).

In the course of historical and pedagogical research on the study of Yurii Stupak's life and activity, it was also necessary to refer to archival documents, in particular from the State Archives of Sumy Region, where the personal fund of the scholar "Stupak Yuriy Petrovych" (Fond R$7443)$ is the most informative. There are 272 cases, made up of materials submitted by his wife Vera Bunakova, arranged according to generic, thematic and chronological classifications.

\section{Methodology}

The methodological basis of the study is the laws and categories of scientific knowledge; principles of scientific research, historicism, systematicity, integrity, unity of the human and national, theory and practice, interconnection and interaction of objective and subjective, traditional and innovative, historical and logical; ideas of expediency of creative use of the best national traditions in the conditions of development of modern education of Ukraine. In the course of the study modern scientific approaches (personally oriented, cultural, personified, interdisciplinary) were applied.

In the course of the research, the following research methods were used: general scientific (analysis, comparison, generalization, systematization), which provided the opportunity to formulate theses and conclusions, identify the leading areas of research; special scientific (using textual analysis, elaboration of the source base and historiographical work on the selected problem; the method of retrospective analysis revealed the successes and difficulties in the formation of Ukrainian national identity in the domestic intelligentsia in the conditions of the Ukrainian statelessness; historical-chronological method or allowed - Stupak's pedagogical worldview; synchronous analysis was used to identify ways of realizing the ideas and experience of the teacher activities of nationally conscious teachers as leaders of the Ukrainian national idea under the conditions of Ukrainian statelessness during Soviet Union times.

\section{Results and discussion}

Modern scholars are unanimous in their thought that development of a national identity is an important component of the concept of personality, formation of which occurs in childhood under the influence of the family environment, friends and acquaintances; later other centers of socialization get involved in this process, such as preschool institutions, schools, extracurricular institutions, institutions of higher education, etc. (Tatanenko, 2010; Potapchuk, 2011). It is the education that becomes an instrument which is able to teach people to defend their identity using powerful resources of national cultural heritage while realizing its significant prognostic potential (Martínez \& Rodríguez, 2016; Makarova, 2019).

The analysis of sources has shown that formation and development of ideological foundations of Yurii Stupak were affected by all the contradictions of the social life of the 20-70-ies of the XX century. Based on the use of cultural and personality oriented approaches, it has been established that formation of Ukrainian national identity of the scholar was influenced by sociopolitical, socio-economic, cultural-educational and personal factors.

Yurii Stupak was born on June 10, 1911 in the village Havrylivtsi, Pavlohrad district, Katerynoslav province (Personal (biographical) documents, SASR). It has been established that Yurii Stupak delicately avoided the question of the composition and characteristics of the family members, their influence on the formation of his personality. It is known that after the death of his father, Petro Stupak, in 1922 the family moved to the Kharkiv region, where in 1927 the boy finished a seven-year labor school in the village Nova Vodolaha, Valkivskyi district, Kharkiv province (Personal (biographical) documents, SASR). The village is known to art historians as an outstanding center of decorative and applied arts, where traditional folk crafts and artisan crafts flourished.

The analysis of sources suggests that Yurii Stupak's first bright impression of childhood was the «demonstration of freedom in 1917» (Danko, 1971). Since many hopes for improving the life of Ukrainian people thrived with overthrowing of autocracy. In the context of elucidation of the socio-political factors in the formation of the outlook of Yurii Stupak it should be noted that 


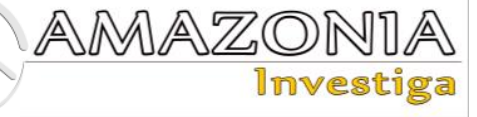

proclamation of the Ukrainian Socialist Soviet Republic was accompanied by the establishment of Marxist-Leninist ideology, suppression of the universal values by class values, that affected formation of a new generation of Ukrainian Soviet intelligentsia.

The childhood and youth of the future teacher coincided with the complicated and at the same time rich period of Ukrainian history - the 20-ies of the XX century, sometimes referred to as "Ukrainian renaissance" in the literature. In 1923, following the announcement at the XII Congress of the Communist Party of the course on "root-fixing" with a tactical aim to strengthen the positions of the Soviet power. The notion of "Ukrainization" was used to define the policy of the Soviet government within the Ukrainian SSR - national in form and socialist in content.

The "Ukrainization" campaign was part of the "cultural revolution" - a radical revolution in the country's spiritual development, covering creation of the socialist system of public education, formation of a new Soviet intelligentsia. Innovative measures included broadening access of citizens to education institutions, elimination of illiteracy of the population, introduction of the native language in education, science and culture, in state authorities, training of Ukrainian pedagogical staff. That is, Yurii Stupak's school and first student years coincided with the time of national upsurge and opening of the new opportunities for development of Ukrainian culture, which had a significant impact on the development of the world perception of a young man, contributed to the formation of his civic position.

At the same time, according to Oksana Homotiuk (2013), representatives of the Soviet government vigilantly observed that the conduct of "Ukrainization" did not go out of control and did not ruin the strategic plan for the internationalization of public life. The narrow ideological orientation of the "Ukrainianization" measures is evidenced by official information about their implementation by 1926 , where the inadmissibility of creating separate courses in Ukrainian studies, conducting exams on the knowledge of Ukrainian studies literature, except a certain minimum within the limits of political charter, was stressed. Despite the loudly declared Ukrainian studies vector in education and science, the literature of the pre-revolutionary period and the national state-building of 19171920 was gradually withdrawn from scientific use as a result of strict censorship. The researcher Larysa Berezivska (2009) has discovered that in the 1920's, conceptually different from the Russian a Ukrainian Soviet system of education developed and tested, based on the principles of professionalism, a unified school, social education, pedocentrism, ideological, work orientation, taking into account national peculiarities.

It should be noted that since the first years of existence, the Soviet government had began a radical restructuring of the education system. The reform of the industry led, first of all, to the closure of classical universities as centers of "pure science" and "bourgeois culture", on the basis of which a number of branch institutes had been created (Pitov, 1967). Yurii Stupak was able to attend Kharkiv Institute of Public Education named after O. Potebnia. So, in 1928, the future teacher began his studies at the courses of preparation for a higher educational establishment, and in 1929 he entered the linguistic and literary department of the school faculty.

It should be noted that Kharkiv Institute of Public Education named after O. Potebnia, created on the basis of the disbanded Kharkiv University, was an outstanding center for the development of the pedagogical theory and practice in Ukraine, with a focus on significant scientific resources. In addition, Kharkiv Institute of Public Education named after O. Potebnia was distinguished among other higher education institutions of the former capital of the Ukrainian Republic as the center of Ukrainian studies; $78,4 \%$ of disciplines in this institution were taught in Ukrainian (Rabchenko,1997).

In the context of the problem under investigation, the role and the fate of the mentors of Yurii Stupak in the Kharkiv Institute of Public Education named after O. Potebnia attracts special attention. From the foundation of the institution (1921), it employed a whole galaxy of talented teachers, representatives of the Departments of Linguistics, History of Ukrainian culture, Literary studies (Dmitro Bahalii, Oleksandr Biletskyi, Leonid Bulakhovskyi, Mikhailo Volobuiev, Mike Johansen, Nataliia Mirza-Avakiants, Mykola Plevako, Oleksa Siniavskyi, Mykola Sulima, Ivan Tkachenko, Ahapii Shamrai, Volodymyr Shchepotiev and others), who made a significant contribution to the development of various areas of Ukrainian studies.

It should be stressed that in Ukrainian literature and ethnology especially fruitfully worked Sumtsov Mykola, who until 1922 headed the 
Department of Literature studies of Kharkov Institute of Education named after O. Potebnia (Mandebura, 2011). Paying tribute to the talented Ukrainian scientist, whose ideas were inspired by several generations of student youth, Yurii Stupak devoted a series of his works to studying his creative heritage.

It should be noted that at that time in Ukraine two powerful philological schools were formed Kharkiv, the organizer of which was Professor Oleksandr Potebnia, and Kyiv, which is associated with the figure of Professor Volodymyr Peretz. We'd like to emphasize that with the first school Yurii Stupak was connected by direct academic connections, and with the second - indirectly, thanks to close cooperation with the active representative of this solid reseach center - Ivan Abramov, who significantly influenced the expansion of the scientific interests of Yurii Stupak.

In the Kharkiv Institute of Public Education named after O. Potebnia, students-philologists were trained on the basis of theoreticalmethodological principles of Kharkiv Philological School and Kharkiv Historical and Philological Society, created to coordinate and popularize studies on history, ethnography, folklore, culture study and philosophy, inducing a thorough analysis of primary sources and author's interpretation of the original texts, critical rethinking of the latest research, the independent compilation of thematic catalogues and bibliography cards, etc. (Cheremska, 2016).

Deepening of the Ukrainian studies component of the content of education was contributed by teaching of local lore, Ukrainian art, ethnography and ethnology at Kharkiv Institute of Public Education named after O. Potebnia (Kashaba, 2010), which was carried out by the efforts of Dmytro Bahalii, Stefan Taranoshenko, Oleksandr Vetukhov. Teachers of Kharkiv Institute of Public Education named after O. Potebnia cultivated a high language culture among the students, formed a sense of responsibility for the development of their native language, raised spiritual nobility, strengthened the motivation to improve the gift of the word, preservation of artistic values and national identity.

We'd like to emphasize that in the content of the teacher-philologist's training of that time a specific share was assigned to social science disciplines. About a third of the study load was devoted to the study of psychologicalpedagogical sciences and teaching methodology of profile subjects. Among the pedagogical disciplines at Kharkiv Institute of Public Education named after O. Potebnia, pedagogy and related disciplines, social education, modern pedagogical trends, history of pedagogy, artistic education were intensively taught (Yarmachenko, 1996). Moreover, the general institute section of the history of pedagogy was headed by the outstanding Ukrainian teacher Yakov Mamontov, whose ideas (concerning pedocentrism, pedagogical creativity, the role of aesthetization in formation of the personality, methods of historical and pedagogical research), in our opinion, influenced formation of the outlook of Yurii Stupak.

Since the purpose of the work of pedagogical institutions of higher education was primarily the ideological and methodological "arming" of the army of "literate schrabs" (school workers), the research work was removed from the environment of higher education and entrusted to academic institutions. In this context, it should be noted that Kharkiv Institute of Public Education named after O. Potebnia qualitatively differed from other higher education institutions, accumulating the faculty with a significant scientific potential and directing training to preparing of research teachers (Bakirov, 2006).

Although at the boundary of the 20-30-ies of the XX century in the writings of scholarshumanitarians of Kharkiv Institute of Education named after O. Potebnia under the pressure of Communist Party guidelines began to appear the signs of "vulgar sociologism", e.i. explanation of all social and cultural phenomena by their class nature, but strong academic traditions of the institution permitted to lay the foundation for the formation of a scientific outlook of students, instill in them love for Ukraine and the native land - Slobozhanshchyna, form a desire to contribute to the rise of Ukrainian science and culture to the world level.

Since the policy of "Ukrainization" contributed to the national-cultural revival of the Ukrainian people, it became one of the reasons for its collapse. At the same time, students and teachers were obliged to take an active part in the social and political life of the region and the country as a whole. In the late 20-ies of the XX century (Yurii Stupak's student years), began mutual harassment, persecution, mass arrests and shootings of the prominent figures of Ukrainian science, education and culture. In the end, the deformation of humanistic values and the underlying principles of family education had a detrimental effect on the spiritual development 


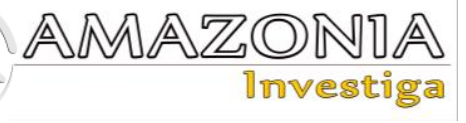

and formation of the personality of many representatives of Ukrainian youth.

Undoubtedly, dramatic socio-political events have affected the character of a capable, thoughtful, self-made young man. Although the mentors managed to lay the ideological and scientific foundations of the future teacher's vision, Yurii Stupak was not forced to mention his teachers and mentors in his own writings or in biographical materials. However, the leitmotif of his activity was revival of the destroyed shrines (human and national dignity, honor of people, freedom of creativity, rehabilitation of the memory of the victims of the totalitarian regime).

Modern scholars Vasyl Marochkov and Goetz Hillig (2003) emphasized that scientificpedagogical elite of Ukraine was positioned by the Chekist structures as pest educators, "nationalistic hostile elements" that "had seized many areas of pedagogical and theoretical work", and consequently, repressive technologies had been applied to them. A number of teachers of the language and literature faculty of Kharkiv Institute of Public Education named after O. Potebnia were shot or wiped out in the camps (Mykola Plevako, Ahapii Shamrai, Oleksa Syniavsky, Mykola Sulim and others). 25 teachers of the Ukrainian culture department were subjected to repressions (Bakirov, 2006). In particular, the well-known specialist in the folk and sacred art of Slobozhanshchyna, Stefan Taranushenko, who taught Ukrainian art in this institute, was sentenced to long-term imprisonment for "an attempt to organize an antiSoviet insurrection" (Kashaba, 2010). In general, during the rule of the Stalinist totalitarian regime thousands of representatives of Ukrainian renaissance were in a difficult position, they became victims of repressive state policy, which made it impossible to resist the punitive system and any signs of dissent.

Synchronous analysis allows us to verify the extent of political repressions in the teaching staff of the native higher schools, which is worth illustrating on the example of Sumy Institute of Social Education (later renamed into Sumy Pedagogical Institute), to which Yurii Stupak devoted about 20 years of his life. According to the study of sources, in 1933-1935, out of 40 teachers of this institution, 29 "class-hostile nationalist elements trying to incite bourgeoisnationalist ideology to students" were dismissed (Korzh, 1999). First of all, suffered the teachers of humanitarian disciplines, who demonstrated the charms of Ukrainian language at their inspirational lectures, revealed the identity of Ukrainian language, history, education, culture, involving students in local studies, archaeological excavations, collection of antiquities and equipment of school museums of local lore. Conducted analysis convinces that Yurii Stupak became the successor of these traditions at Sumy Pedagogical Institute in the later historical period.

Formation of the outlook of Yurii Stupak, as well as many representatives of Ukrainian youth, also affected the socio-economic processes that took place in the country (forced industrialization, urbanization, forced collectivization, and the dismantling of the peasantry), as a result of which the agrarian country turned into an industrial one. At the same time, the state policy of the Holodomor of 1932-1933, which took the lives of millions of Ukrainians, led to the decline of the traditional village - the cradle of Ukrainian spirituality with its centuries-old educational practices and traditions, folk crafts and pedagogy.

Having received a higher education, Yurii Stupak was tempted to go to work at Okhtyrka Pedagogical School, an institution that for some time carried the name of a well-known writer and teacher Borys Hrinchenko, and subsequently undergone transformations from a pedagogical school and a seminary to higher pedagogical courses and technical school (Korzh, 1999). It should be emphasized that in the 20-30-ies of the XX century in Okhtyrka functioned a literaryartistic cell of creative Ukrainian youth, in which participated Borys Antonenko-Davydovych, Ivan Bahrianyi, Ivan Vyrhan, Matvii Dovhopoliuk, Yurii Sambros and others (Sambros, 1988). that had mediated influence on the formation of Yurii Stupak's Ukrainian national identity. However, most of its representatives - masters and fans of the Ukrainian word -were repressed.

The analysis of sources shows that professional self-affirmation of Yurii Stupak as a teacher and scientist was characterized by certain negative phenomena in the development of education centralization and sectoral unification, which led to curtailment of creative activity of teaching, deepening of ideologization, ignoring of national peculiarities of different regions of the country, standardization, authoritarianism, sovietization and Russification. The ideal of educating a heroic Soviet man, "an active fighter of the ideological front" was propagated. In each branch of public life (especially in school) there were rules, instructions, norms regulating the relations 
between teachers and students, aimed at the cultivation of ideology, unquestioning devotion to social ideals, collectivism, duty, combined with discipline. According to modern scholars, in particular Olha Sukhomlynska (2009), Anton Makarenko implemented this concept the most fully (the ethics of collectivism, will, courage, and purposefulness).

The leading tasks of Soviet pedagogy were: "scientific development" of the questions of formation of the communist consciousness of the younger generation, education of the foundations of Marxist-Leninist worldview, high ideology and devotion to communism, intransigence to hostile ideology, communist attitude to labor and social economy, high moral qualities, study of ties between education and development, the conditions under which the comprehensive development of the individual takes place (Prokop, 2007). This led to the deepening of the ideological component of the future teacher's training, proclamation that pedology was pseudoscience, domination of socio-scientific disciplines in the content of education, destroying of the national traditions and culture, rejection of the individuality and uniqueness of the child, strengthening of atheistic, international and military-patriotic education.

During the World War II, the majority of higher education institutions were evacuated to the east, most of the teachers and students - were called to the ranks of the Red Army. This fate didn't passed by Yurii Stupak. After the liberation of the territory of Ukraine from the Nazi invaders, serious problems in the development of the higher school were the destruction of the material-research base of the higher schools, reduction of the creative potential of society, lack of scientific-pedagogical staff. It was conditioned not only by scientific losses, but also by the actions of Soviet bodies of state security (Bystra, 2009). The analysis of the sources convinces that during this period the main task of the teacher of higher school lied not in providing the future specialists with a high level of knowledge, but in revealing the leading driving force of the Communist Party in the development of society.

It is worth noting that after captivity and passing the appropriate examination, Yurii Stupak managed to return to his pedagogical activity. However, creative work of the scientist of the late 40-ies and early 50-ies, written in the context of the merger of two cultures, is characterized by forced ideological engagement, which allowed him to avoid criticism as a representative of the "nationalist literary critics".

The priority of Yurii Stupak's activities in the second half of the 40-ies - in the early 50-ies was to prepare a dissertation entitled "The Slavic subject in the Ukrainian Literature of the 40-50ies of the XIX century", in which the work of the well-known Ukrainian writers was studied in the context of activity of Kharkov romantics, "Russian trinity" and so-called "Slavic question" (Stupak Yu. P. Slovenic theme, SASR). In 1953, successful defense of the dissertation research for obtaining a scientific degree of the candidate of philological sciences took place. It should be noted that one of the reviewers of the dissertation was Doctor of Philology, Academician Maksym Rylskyi. We'd like to stress that from the end of the 50-ies to the early 70-ies, Yurii Stupak actively worked on his doctoral dissertation on the topic "Essays on the history of Ukrainian child literature of the XIX - early XX century", the manuscript of which (in the volume of more than 350 sheets) is stored in his personal fund at the State archive of the Sumy region (Stupak Yu. P. Essays on the History, SASR).

The times of the Khrushchev's thaw (the second half of the 50-ies - the first half of the 60-ies of the XX century), when at the XXth Congress of the Communist Party a course was announced to eliminate Joseph Stalin's "cult of the personality" and rehabilitate victims of political repression, identified a slightly different sociopolitical situation in Soviet society. The driving force of the rehabilitation process was public opinion, aimed at restoring the inflexibility of the names of representatives of the scientific and creative intelligentsia, which was actively supported by the Academy of Sciences of the Ukrainian Soviet Socialist Republic, creative unions, and a number of public organizations (Misinkevych, 2003). Evidence of Yurii Stupak's active participation in this process was his fruitful interaction with well-known repressed scholars Ivan Abramov (condemned in the case of the Slavists) and Stefan Taranushenko (accused of "counter-revolutionary activity"), an appeal to the legacy of undeservingly forgotten scholars, writers and artists that were accused of "bourgeois nationalism" (Ivan Vyrhan, Borys Hrinchenko, Oleksandr Oles, Nykanor Onatskyi, Ilarion Sventsytskyi, Mykola Sumtsov, Yakov Shcheholiv, et al.), highlighting the activities of Leningrad Branch of Ukrainian Studies, headed by Professor Volodymyr Peretz - Branch of the All-Ukrainian Academy of Sciences. We'd like to note that at that very time, in the creative work of Yurii Stupak, there appeared first thorough 


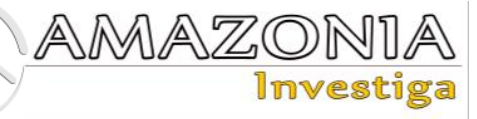

studies devoted to the problems of upbringing of the younger generation on the nationalpedagogical sources (Pohilko, 2017).

This time is marked by a certain democratization of society, the scientific-technical revolution, restructuring of the economy, establishment of an active social policy of the state, the need for highly educated workers for various sectors of the national economy, which had become a catalyst for the revival of creative pedagogical initiative, the "second wave of Ukrainization", a dissident movement aimed at democratization, observance of human rights and freedoms, free development of Ukrainian language (Bulgakova, 2013). It should be noted that many members of the dissident movement in Sumy were associates and pupils of Yurii Stupak (Mykola Danko, Volodymyr Zatulyviter, Ivan Korniushchenko, Hennadii Petrov, Anatolii Semeniuta, Yurii Tsaryk et al.), promoting the ideals of the revival and development of Ukrainian culture.

Many Ukrainian newspapers and magazines (including scientific ones) were published in Ukrainian, and their share in the market of printed periodicals was almost $80 \%$ (Kostytski, 2016). Such policy of the Soviet government was widely supported by the Ukrainian intelligentsia, in particular Yurii Stupak, who, on the pages of his works, welcomed the quantitative and qualitative growth of Ukrainian literature.

The researchers have determined that positive results of the educational reform during the "Khrushchev's thaw" were democratization of internal school life and management of education, intensification of pedagogical research for ensuring the scientific basis for reform. This period is marked by research in the field of pedagogical knowledge, optimization of the educational process, the course on strengthening the social nature of education, overcoming the separation of learning from life. The paradigm of education was characterized by the communist orientation, the belief in the omnipotence of educational influences on students, teachers, parents, the public, student organizations, the attempt to develop all the basic groups of personal qualities of schoolchildren, orientation to standard approaches to education (Pantiuk, 2011).

At the same time, innovative concepts, ideas, forms and methods appeared, among which the work of the teacher-humanist Vasyl Sukhomlynskyi was distinguished. It was Vasyl Sukhomlynskyi who was able to fully reveal the spiritual and ethical issues that faced the young person by introducing the category of spirituality into the pedagogical context ("Spiritual world of a student of teen and juvenile age"), pedagogical ethics ("How to educate a true person" and "A Book on Ethics"). Later was published Vasyl Sukhomlynskyi's book "Parental Pedagogy", which was marked by a specific ethnopedagogical potential (Sukhomlynsky, 1976).

In the context of our work, we'd like to note that while preparing the works for publication, Vasyl Sukhomlynskyi, so as Yurii Stupak, had to remove from the text a number of considerations that did not correspond to the dominant state ideology. After all, according to Olha Sukhomlynska (2012), in the handwritten originals of Vasyl Oleksandrovych's works, there was markedly "much in common with the tendencies and trends that existed at that time outside of the Soviet discourse". Contrary to the prevailing authoritarian approaches, in the midsixties of the twentieth century the conceptual foundations of modern pedocentric tendencies were laid in the writings of the prominent Ukrainian educator. Vasyl Oleksandrovych created an original pedagogical system, based on the recognition of the child as the highest value of the pedagogical process and society as a whole. Along with the love for the Motherland and Labor Vasyl Oleksandrovych promoted man-centeredness and humanism. The basis of the scholar's outlook was the idea of cordocentrism inherent in traditional Ukrainian philosophy.

On the principles of humanism, national educational traditions, tolerance and mercy, were also based the concepts of education of other well-known teachers of the second half of the XX century (Ivan Tkachenko, Oleksandr Zakharenko, et al.).

Like these teachers-practitioners, Yurii Stupak for his whole life worked in the field of education, therefore, transformations in society and education system, the adoption of a number of normative documents that determined the directions of research and the requirements for the preparation of the pedagogical staff, updating of methodological approaches to education, gradual departure from authoritarian pedagogy to humanistic, had a significant influence on the establishment of his national identity.

However, shortly after the "Khrushchev's thaw" period came the era of "Brezhnev's stagnation", began a deep systemic crisis in Soviet society, which ultimately led to the collapse of the economy and political collapse of the USSR. 
Educational transformations of this period were aimed at the expansion of the school network, intensive development of pedagogical science, Russification and Sovietization. These steps envisaged, first of all, assimilation of Ukrainian people into the Soviet community, which led to a number of negative consequences: prevalence of schools with Russian language of instruction or absence of schools with Ukrainian language of instruction in cities; transition of the urban population to communication in Russian; perception of the mother tongue as a minority language by Ukrainians; deformation of the national consciousness, spiritual degradation of many generations of Ukrainian people.

Without a doubt, Yurii Stupak was a man of his time, so all the contradictions and complexities of the historical epoch of the twentieth century could not but affect his life. According to the memoirs of his contemporaries, he was forced to analyze and think about every word, every conclusion, he was not a dissident in the modern sense of the word, never went beyond the requirements of the time, did not officially criticize party politics, did not speak with antiSoviet appeals. However, the analysis of archival materials shows that Yurii Stupak had repeatedly been blamed for insufficient attention to the illumination of the views of the classics of Marxism-Leninism and lack of references to the decisions of the Communist Party and the Soviet government (Reviews, SASR).

According to his numerous students, the researcher «persistently and consistently ascertained the national nature and national originality of one or another phenomenon, focused attention at the national problems in literature, art, and pedagogy» (Vertii, 1996). In the difficult historical period, the life of Yurii Petrovych was devoted to the noble work of education and upbringing, which made it possible to influence duly the development of spiritual world of his young compatriots, raising their respect for their native word, culture, history.

One of the students of Yurii Petrovych, Doctor of Philology, Oleksii Vertii, confirmed this opinion. Oleksii Ivanovych testified that he "still feels himself in the captivity of his perfectly pure, majestic and enchanting world of Ukrainian spirituality" and although he "has never - in lectures or in private conversations - officially expressed criticism in the address of the Soviet state and its avant-garde" (the Communist Party of the Soviet Union), but "has always been able to direct an opinion on the anti-human subtext of their ideology and politics" (Vertii, 1996). The talented teacher applied a creative approach to teaching, uniting students in the world of Ukrainian science and culture.

Organization of the public for rescuing from the destruction of the Resurrection Church in Sumy, an outstanding monument of the Cossack Baroque in Slobozhanshchyna, which was planned to be demolished in 1960, was a testimony to the civic courage and stability of the established Ukrainian national identity of Yurii Stupak (Artiukh, Ivanushenko \& Sadivnychy, 2012). It is worth noting that social activity, which was one of the characteristic features of Yurii Stupak, was positioned by the scientist as a component of an extremely important pedagogical educational mission through direct contact with people.

It should be emphasized that since the mid-sixties of the twentieth century, that is, at the end of the Khrushchev era of "liberal communism", the prosecution for dissent was restored. In order to prevent the development of national consciousness of the citizens, the authorities eliminated from the responsible positions and dismissed nationally conscious and authoritative teachers, journalists, and heads of different levels. Modern researchers point out that the same fate had the head of the Department of Ukrainian Literature of Sumy State Pedagogical Institute named after A. S. Makarenko Yurii Stupak. In order not to allow him to defend almost prepared doctoral dissertation, Yurii Petrovych was retired, and in his place were appointed teachers who were loyal to the communist regime (Artiukh, Ivanushenko \& Sadivnychy, 2012). In addition, there also was not admitted to teaching at the Department of Ukrainian Literature the poet Volodymyr Zatulyviter - a pupil and friend of Yurii Stupak.

\section{Conclusions}

Thus, the study of the sources indicated the continuity of the process of forming Ukrainian national identity, despite all the difficulties and metamorphoses of the historical era of the Soviet period. It has been proved that even during the time of significant socio-political, socioeconomic, cultural and educational changes, when the targeted leveling, standardization and ignoring of national interests of the person was carried out, the process of forming of Ukrainian national identity in the whole galaxy of the native intelligentsia continued. The study of the vicissitudes of the personal formation of the teacher and scientist Yurii Stupak allowed to 


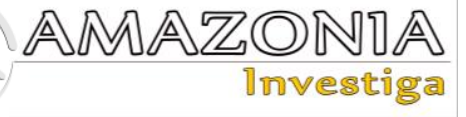

state that native intellectuals, brought up in folk traditions, studying in the best, conscious of their roots teachers, through self-education as a guarantee of the integrity of the individual (unity of beliefs and actions), striving for constant personal and professional self-improvement, became leaders and active propagandists of the Ukrainian national idea, contributing to the development of individual peculiarities, professional qualities and active life position of their students by involving them in the language and culture of their people.

\section{Bibliographic references}

Artiukh, V. O., Ivanushenko, G. M. \& Sadivnychy, V. O. (Eds.). (2012). Dissent in Sumy region: collection of documents and materials (1955-1990). Sumy, Ukraine: «Mria-1»

Bakirov, V. S. (2006). Kharkiv national university named after V. N. Karazin: timeline. Local lore [Local history], vol. 1-4,

pp. 121-125.

Berezivska, L. D. (2009). Organizationalpedagogical foundations of reforming school education in Ukraine in the $\mathrm{XX}$ century $(\mathrm{PhD}$ thesis). Institute of Pedagogy, Academy of Pedagogical Sciences of Ukraine, Kyiv, Ukraine. Bulgakova, O. (2013). Scientific-pedagogical intelligentsia of Ukraine (mid-1950 - first half of the 1960) as an object of state policy. In V. M. Danylenko (Ed.). Ukraine in the 20th century: culture, ideology, politics: collection of works (V. 18, p. 232-245). Kyiv, Ukraine: Nat. acad. Sciences of Ukraine, Institute of History of Ukraine.

Bystra, M. (2009). Scientific-pedagogical intelligentsia of the UkrSSR in 1943-1945: Life and work in the war conditions. Scientific letters of Ternopil State University named after Volodymyr Gnatiuk. Series: history, vol. 2, pp. $181-188$

Cheremska, O. (2016) Origins of Kharkiv philological school and Potebnia's nationallanguage traditions. Ukrainska mova, vol. 2, pp. 92-111

Danko, M. (1971). Spring furrows of the researcher. Creative portraits: Yu. P. Stupak. Leninsk is true, 9, June.

Gomotiuk, O. (2013). Controversy of the policy of "Ukrainization" and its influence on the development of Ukrainian studies. Retrieved from:

http://lohocoust.blogspot.com/2013/10/superech lyvist-polityky-ukrayinizaciyi.html

Kashaba, O. Yu. (2010). Contribution of educators of the Kharkiv Region to the development of local history studies in the 20-s and early 30-s of the XX century. Kharkiv, Ukraine: Hark. nat. un-t.

Korzh, L. V. (1999). History of formation and development of the Sumy State Pedagogical University named after A. S. Makarenko. Sumy, Ukraine: SumDPU.

Kostytski, M. V. (2016). Psychological, legal and political aspects of the introduction of Ukrainian language as a state language. Legal Psychology, vol. 2 (19), pp. 9-19

Makarova, T. (2019). Concept «identity» in antique philosophical discourse. Amazonia Investiga, vol. 8, num. 19, pp. 207-211 Mandebura, O. S. (2011). Mykola Sumtsov and problems of socio-cultural identity. Kyiv, Ukraine: Institute of Political and Ethnonational Studies.

Marochko, V. \& Hillig, G. (2003). Repressed teachers of Ukraine: victims of political terror (1929-1941). Kyiv, Ukraine: Naukovyi svit. Misinkevych, L. L. (2003). Rehabilitation of the scientific and creative intelligentsia in the second half of the 50-ies - 60-ies of the 20th century. In P. T. Tronko (Ed.). History of Ukraine. Littleknown names, events, facts: a collection of articles (V. 22-23, p. 374-389). Kyiv, Ukraine: Nat. acad. Sciences of Ukraine, Institute of History of Ukraine.

Pantiuk, M. P. (2011). Preparation of the future teacher for educational work in the national pedagogy of the $\mathrm{XX}$ century. ( $\mathrm{PhD}$ thesis in Education). Drogob. State Ped. Univ. I. Franko, Drohobych, Ukraine.

Pitov, V. I. (Eds.). (1967). Higher school of the Ukrainian SSR for 50 years (1917-1967). (V. 1: 1917-1945 years). Kyiv, Ukraine: Editorial of Kyiv University.

Pohilko, O. V. (2017). Yurii Petrovych (19111979): catalog of works. Sumy, Ukraine: IE Tsioma S. P.

Potapchuk, T. (2011). Formation of the national identity. Retrieved from: library.udpu.edu.ua/library_files/zbirnuk_nayk_ praz/2011/2011_2_36.pdf (in Ukrainian).

Prokop, I. S. (2007). Historical and Pedagogical Analysis of the Purpose of Education in the Soviet School of the 1950-1980's. Scientific Herald of Chernihiv University. Series: Pedagogy and Psychology, vol. 342, pp. 137149.

Rabchenko, O. L. (1997). Kharkiv institute of public education named after O. Potebnia (1921-1930). (Abstract of $\mathrm{PhD}$ thesis in History). Dnipropetrovsk. State Un-t., Dnipropetrovsk, Ukraine.

Rodríguez, E., Martínez, I. (2016). La educación patrimonial. Consideraciones sobre su contribución al proceso de educación. Amazonia Investiga, vol. 5, num. 9, pp. 82-90 
Sambros, Yu. (1988). Stages: My Way to Communism. [Without a place of publication], Ukraine: Suchasnist

Sukhomlynska, O. (2012). In the search of real. In V. Suhomlynsky. To Children I Give My Heart (pp. 5-23). Kyiv, Ukraine: Akta. Sukhomlynska, O. V. (2009). Pedagogical ideal through the prism of theories of morality. Pedagogical sciences, vol. 1, pp. 5-15

Sukhomlynsky, V. O. (1976). Selected works. (V. 1-5). Kyiv, Ukraine: Radianska school.
Tatanenko, T. M. (2010). Regional identity in the political space of Ukraine. Gileya: scientific herald, vol. 30.

Vertii, O. (1996). Island of the Ukrainian spirit. 85 years since the birth of Yurii Petrovych Stupak. Chervonyi promin, 27 december.

Yarmachenko, M. D. (Eds.). (1996). Institute of Pedagogics of Academy of Pedagogical Sciences 70-year anniversary. Kyiv, Ukraine: Pedagogical thought. 